\title{
LUISA ROLDÁN EN SEVILLA Y SAN JOSÉ CON EL NIÑO JESÚS: ATRIBUCIONES E ICONOGRAFÍA
}

\section{LUISA ROLDÁN IN SEVILLE AND ST JOSEPH WITH THE CHILD JESUS: ATTRIBUTIONS AND ICONOGRAPHY}

\author{
Alfonso Pleguezuelo Hernández \\ Universidad de Sevilla. España \\ aplegue@us.es
}

\begin{abstract}
Se abordan en este artículo tres cuestiones. Primero son enumeradas algunas esculturas de San José con el Niño Jesús que han ido siendo atribuidas a Luisa Roldán en los últimos años hasta crear una imagen relativamente verosímil de su forma de interpretar este importante asunto de la iconografía barroca española. Se proponen a continuación dos nuevas obras que pudieran ser incorporadas a su catálogo. Finalmente se sugiere como una posible fuente de inspiración del modelo iconográfico que sigue esta artista los textos de una obra literaria que fue una de las más leídas en aquella época en el género de la literatura devocional.

Palabras claves: Roldana; escultura; Barroco; San José; literatura devocional.
\end{abstract}

Three issues are addressed in this paper. First are listed some sculptures of St. Joseph with the Child Jesus that have been attributed to Luisa Roldán in recent years to create a relatively plausible image of how she interpreted this important subject of Spanish Baroque iconography. Next, two new works are proposed that could be included in its catalog. Finally, it is suggested one hypothetical source of inspiration of the iconographic pattern that this artist followed for this subject: the texts of one of the most read literary works at that time within devotional literature.

Keywords: Roldana; sculpture; Baroque; Saint Joseph; devotional literature.

En homenaje a un amigo y colega que me honra con su invitación a participar en este volumen y a quien debemos tantos esfuerzos en el estudio de la imaginería y de la escultura religiosa, resultará lógico que le dedique y proponga aquí a debate algunas nuevas atribuciones de obras a una escultora del periodo barroco, Luisa Roldán, y que, de paso, sugiera una hipótesis sobre la posible deuda de la variante iconográfica del tema de San José con el Niño que sigue esta escultora con su eventual fuente de inspiración en una obra literaria de la época. 
Se conocen desde hace tiempo las interpretaciones que de este personaje, en distintas actitudes, hizo la escultora en su etapa madrileña. Suelen estar integradas en sus pequeños grupos de terracota. Y también se conoce alguna imagen de madera, por cierto, de calidad extraordinaria, que se conserva por razones hasta ahora desconocidas en un convento andaluz, el de Nuestra Señora de Belén, en Antequera (Málaga) (Figura 1) ${ }^{1}$.

En los casos que a continuación abordamos también nos referiremos precisamente a versiones, como ésta, talladas en madera aunque ahora se trate de obras que se conservan en Sevilla y que, según estimo, tienen un claro origen andaluz. Darlas a conocer no solo tiene como fin añadirlas eventualmente a su catálogo sino también calibrar la posibilidad de que las mismas pudieran allanar el terreno al estudio de esta etapa menos conocida de su producción. Las esculturas a que aludiré nos hacen replantear una de las hipótesis de trabajo, manejada hasta hace poco por algunos autores, según la cual sus interpretaciones juveniles podrían estar camufladas entre las obras de su padre y maestro Pedro Roldán por su supuesta semejanza con éstas. Por el contrario, las que aquí aportaremos, como otras recientemente publicadas, parecen más bien apuntar en una dirección diferente que presentaría la obra temprana de la joven Luisa, al menos en algunos casos, distinguible respecto de la de su progenitor. Por otra parte, las obras que mencionaremos también suscitan un asunto aún más complejo de demostrar que el anterior como es el de los diferentes grados de responsabilidad que pueden adjudicarse al maestro de un obrador o a sus oficiales -en este caso la colaboración de su marido Luis Antonio de los Arcos sería la fundamental- en las esculturas salidas del mismo. Ambos asuntos, vista su complejidad, tan solo serán aquí sugeridos.

En los últimos años se han realizado, en medios científicos, varias atribuciones a la Roldana de imágenes de San José con el Niño de las que la mayoría han sido unánimemente aceptadas. Entre ellas una de las primeras fue una pequeña pero fina escultura conservada en la catedral de Salamanca, de indudable paternidad, aunque parece obra tal vez de taller ${ }^{2}$. El autor que la dio a conocer no la vinculó a una etapa concreta de la vida de la artista aunque los paralelos formales en que basó su opinión los estableció, obviamente, con las únicas versiones de este tema conocidas en aquel momento: las incluidas en sus grupos de terracotas, madrileños (Figura 2).

${ }^{1}$ La obra fue publicada por vez primera por ROMERO BENÍTEZ, Jesús: "El patrimonio artístico de las clarisas de Antequera", en Las clarisas de Antequera. Santa Clara de la Paz y de Belén. Antequera, 2006, pp. 96-126; y ROMERO BENÍTEZ, Jesús: ficha de catálogo de San José en ROMERO TORRES, José Luis y TORREJÓN DÍAZ, Antonio (coords.): Roldana. Sevilla, 2007, p. 222.

2 MARTÍNEZ ALCALDE, Juan: "Una nueva obra para el catálogo de la Roldana", Boletín de las Cofradias de Sevilla, 376, 1991, pp. 44 y 45. 
Comparto plenamente aquella atribución aunque considero que pudo ser obra de su fase sevillana que ahora vamos conociendo algo mejor que entonces. De hecho, alguna indagación de archivo que he realizado me ha conducido a barajar la posibilidad de que fuese llevada a Salamanca por un canónigo sevillano de origen flamenco que estuvo destinado en aquella ciudad, Adrians Conique, sobrino del célebre Nicolás Antonio ${ }^{3}$.

Vinculable a este tipo de obras menores, ha sido dada conocer otra más recientemente que apareció en el comercio sevillano y que conocimos gracias a la llamada de atención de un amigo, buen conocedor de nuestra escultura ${ }^{4}$. Esta segunda obra fue publicada algún tiempo después, atribuyéndola a la producción de Luisa Roldán de forma convincente con un detenido análisis formal ${ }^{5}$.

Una versión inédita del mismo tema que aún se conserva en la clausura del convento sevillano de la Madre de Dios, obra de interés aunque con problemas de conservación, podría pertenecer a este mismo género de piezas que pudieron salir del obrador sevillano de Luisa Roldán aunque tal vez sin su participación material directa (Figura 3$)^{6}$. Tal vez no se trataba, en estos últimos tres casos mencionados, de obras hechas por encargo sino de aquellas más modestas, fabricadas para clientes anónimos y cuya venta en la tienda abierta al público estaría implícitamente asegurada gracias a la devoción que despertaban sus advocaciones entre los feligreses locales.

${ }^{3}$ Su posible donante podría ser Adrián Jesús Conique, sobrino del también canónigo de la catedral de Sevilla, caballero de la Orden de Santiago y fiscal del Consejo de Cruzada Nicolás Antonio Conique (Sevilla, 1617-Roma, 1684). Este personaje fue célebre, como se sabe, por su importantísima obra recopilatoria de autores españoles Biblioteca Hispana Vetus (Roma, 1696) y Biblioteca Hispana Nova (Roma, 1672, reed. Madrid, 1783). El propio Nicolás Antonio había estudiado Jurisprudencia en Salamanca en 1639 y mantuvo su relación posteriormente con la Universidad de dicha ciudad. Su sobrino fue nombrado canónigo de dicha catedral por bula de Inocencio XI expedida en Roma el 15 de enero de 1681, plaza de la que toma posesión el 16 de abril de dicho año. Sabemos, por otro lado, que Adrians fue heredero universal de su tío Nicolás y que el 23 de mayo de 1687 donó al cabildo catedralicio salmantino un arca con el cuerpo de San Teodoro, heredada de su tío quien la había comprado en Roma (Archivo de la Catedral de Salamanca, caja 44 bis, doc. 46). Desconocemos si esta escultura de San José formó parte de la herencia familiar o si había sido comprada por el propio Adrián, quien dejó su Sevilla natal cuando aún vivía en ella Luisa Ignacia Roldán.

${ }^{4}$ Debí aquella información a Juan Randado Pérez, quien la localizó en los expositores del anticuario sevillano que la puso en circulación comercial después de adquirirla de manos privadas. El propio Martínez Alcalde alertó también de esta posible novedad.

${ }^{5}$ ROMERO TORRES, José Luis: "Saint Joseph and the Child", en catálogo de la exposición The mistery of faith, An eye on Spanish Sculpture 1550-1759. Londres, 2009, pp. 172-179.

${ }^{6}$ El conocimiento de esta obra lo debo a Manuel Espinal, a quien agradezco haya compartido conmigo esta información. 
También en estos últimos años se han dado a conocer varias imágenes de San José, integradas en diferentes variantes del episodio del Nacimiento de Cristo. Todas ellas fueron talladas en madera, como los relieves de la Adoración de los Pastores y de los Reyes Magos, respectivamente, ambos en el retablo de la iglesia colegial de Zafra (Badajoz) o las pequeñas figuras exentas de sus grupos de belenes sevillanos ${ }^{7}$. Todas ellas suministran una valiosa información plástica acerca de cómo Luisa Roldán interpretaba el tema de San José durante sus años juveniles andaluces y permiten comparar sus rasgos con los de sus posteriores versiones madrileñas y también con los de las obras de su padre y de otros contemporáneos.

Un género diferente por su mayor tamaño, su colocación y su función es el de las esculturas ejecutadas para ser colocadas en las hornacinas de los retablos. De éste se han publicado recientemente dos obras que le pueden ser atribuidas con bastante seguridad. Una de ellas es la conservada hoy en el retablo mayor de la iglesia del convento de Santa Ana, de Sevilla (Figura 4) ${ }^{8}$.

Del mismo material aunque de calidad más modesta y lamentablemente con la policromía muy transformada, es la que se conserva en el convento de madres dominicas, hoy en Bormujos (Sevilla) (Figura 5) ${ }^{9}$.

En relación con las obras mencionadas hasta aquí, aunque presentan interesantes matices diferentes entre ellas, parece haber cierto consenso respecto de su atribución a la artista o a su obrador pero la autoría de las tres que mencionaré a continuación ha sido objeto de un cierto debate que aún hoy sigue abierto ${ }^{10}$. El mayor obstáculo para despejar estas dudas de paternidad reside en que son muy pocas las imágenes de este tema claramente documentadas de los escultores sevillanos contemporáneos de la Roldana como son su padre Pedro Roldán,

7 PLEGUEZUELO, Alfonso: "Entre el decoro y la licencia. Nuevas obras atribuibles a Luisa Roldán en Zafra (Badajoz)", Laboratorio de Arte, 28, 2016, pp. 171-177; DOBADO, Juan: "Un Nacimiento desconocido de la Roldana", Myriam, Revista mariana Universal, 65, 2011, pp. 196-197; PLEGUEZUELO, Alfonso: "Cuatro Belenes inéditos de la Roldana", Ars Magazine, 9, 2011, pp. 80-93; y PLEGUEZUELO, Alfonso: "Los cuatro Reyes Magos de Luisa Roldán”, Ars Magazine, 30, 2016, pp. 108-118.

${ }^{8}$ PLEGUEZUELO, Alfonso: "Luisa Roldán y el retablo sevillano", Laboratorio de Arte, 24, 2012, pp. 275-300.

9 HERRERA GARCÍA, Francisco y PÉREZ DE TENA, Ana: "Un San José atribuido a la Roldana en el convento de Santa María la Real de Bormujos, Sevilla”, Atrio, 17, 2011, pp. 59-68.

${ }^{10}$ No me parece tan clara la atribución a su labor que se hace en el trabajo de GARCÍA OLLOQUI, María Victoria: "La Iconografía de San José con el Niño en dos obras de segura atribución a la Roldana”, Espacio y Tiempo. Revista de Educación Física, 19, 2005, pp. 91-109; y GARCÍA OLLOQUI, María Victoria: "Algunas atribuciones a la Roldana y seguidores aventajados", en GONZÁLEZ GÓMEZ, Juan Miguel y MEJÍAS ÁLVAREZ, María Jesús: Estudios de Historia del Arte, Centenario del Laboratorio del Arte (1907-2007). T. II. Sevilla, 2009, pp. 171-186. 
Alfonso Martínez, Andrés Cansino, Francisco Ruiz Gijón y otros más de los que ni siquiera conocemos sus nombres pero que debieron estar en activo durante el último tercio del siglo XVII.

Todos los autores que han escrito sobre Pedro Roldán en relación con este tema recogen una noticia dada en 1671 por Fernando de la Torre Farfán quien describe una imagen de San José con el Niño en brazos que estaba situada en aquel momento en el retablo dedicado a éste, a los pies de la catedral y junto a la capilla de San Laureano ${ }^{11}$. Después de Farfán, otros escritores mencionan la obra y la vinculan igualmente a este autor. Son los casos de Palomino (1714), el conde del Águila y Ponz (1786), Arana de Varflora (1789), Ceán Bermúdez (1800) y, más modernamente, Salazar (1949), Bernales (1973) o Roda (2014) ${ }^{12}$. La imagen ya estaba ejecutada en 1664 cuando Juan Valdés Leal la menciona en el "rretablo de san Joseph que esta junto a dicha capilla (se refiere a la de San Laureano)" al contratar la policromía de ambos ${ }^{13}$. A favor del carácter de prototipo de aquella obra que Roldán hizo para la catedral podría citarse una noticia posterior según la cual ésta fue tomada como modelo para otra escultura del mismo tema en $1689^{14}$. No está aquella imagen en su lugar desde hace mucho tiempo y diferentes autores han intentado identificarla con alguna de las conservadas en el templo mayor de la ciudad, habiéndose llegado a un acuerdo casi general de que se trata de una que actualmente se expone en el museo catedralicio. Es obra que muchos autores consideran atribución segura aunque no puedo ocultar que llama mi atención su discreta calidad que no parece corresponderse ni con la fama de la obra ni con la calidad de la mejor producción conocida hoy de la gubia de Pedro Roldán, a pesar de estar destinada a un cliente tan exigente.

De una calidad muy superior es, sin embargo, una imagen conservada en la actual capilla de San José -antes de San Nicolás Tolentino-, del Sagrario de la catedral, escultura anónima que algunos asignan a Pedro Roldán y que, incluso, fue propuesta hipotéticamente hace algún tiempo como posible obra de su hija

${ }^{11}$ DE LA TORRE FARFÁN, Fernando: Fiestas de la Santa Iglesia Metropolitana y patriarcal de Sevilla. Al nuevo culto del señor Rey S. Fernando. Sevilla, 1671, p. 173.

12 PALOMINO, Antonio: El Parnaso español pintoresco y laureado... T. III, Madrid, 1714, p. 1008; PONZ, Antonio: Viage de España. T. IX. Madrid, 1786; ARANA DE VARFLORA, Fermín: Compendio Histórico y Descriptivo de la muy noble y muy leal ciudad de Sevilla. Sevilla, 1789; y CEÁN BERMÚDEZ, Juan Agustín: Diccionario... Madrid, 1800, p. 243. Más modernamente, han recogido esa noticia SALAZAR, $\mathrm{M}^{\mathrm{a}}$ Dolores: "Pedro Roldán, escultor", Archivo Español de Arte, XXII, 1949, p. 326; BERNALES, Jorge: Pedro Roldán, maestro escultor. Sevilla, 1973, p. 66; y RODA PEÑA, José: Pedro Roldán, escultor, 1624-1699. Madrid, 2012, p. 316.

${ }^{13}$ KINKEAD, Duncan: Juan Valdés Leal (1622-1690), His Life and Work. Nueva York y Londres, 1978, pp. 543-544.

${ }^{14}$ DÁVILA-ARMERO DEL ARENAL, Álvaro y PÉREZ MORALES, José Carlos: Pedro Roldán. Vol. II. Sevilla, 2008, p. 99. 
Luisa ${ }^{15}$. No obstante, no deberíamos descartar la posibilidad de que fuera obra de su padre e incluso, pienso, que fuese esta escultura a la que se refiere Farfán ${ }^{16}$. Y no soy el único que opina de esta forma según he podido comprobar en conversaciones personales con otros colegas que se han manifestado en este mismo sentido $^{17}$. Desde luego, la del Sagrario, en comparación con la del museo catedralicio, refleja una calidad escultórica muy superior y una estética muy cercana al mejor Pedro Roldán.

Es preciso indicar que ni ésta obra ni la antes mencionada, por la incomunicación que reflejan padre e hijo, parecen responder a un curioso comentario que Farfán hacía de la obra de la catedral en 1671 al afirmar que están “...bien significados los cariños de ambos semblantes" lo que constituiría un testimonio literario que induce a pensar que ya Roldán hubiera podido iniciar la línea de expresiones afables cargadas de sentimientos que su hija desarrollaría con mayor decisión. No cabe, sin embargo, pensar que la obra a que alude Farfán fuese hecha por Luisa quien en 1664, cuando Valdés le da color y encarnaduras, contaba solo con doce años de edad.

Sin embargo, otra escultura que algunos consideramos muy próxima al nivel de calidad de Roldán y que refleja algo de estos sentimientos, es la que se conserva en el ático del retablo del Cristo del Amor, en la iglesia colegial del Salvador, de Sevilla, obra que ha sido también atribuida a este autor por Gómez Piñol con base no solo en sus formas sino también en la noticia de un inventario de principios del siglo XVIII que menciona una obra de este tema en el mismo templo y la atribuye al maestro ${ }^{18}$. A pesar de resultarnos convincente esta posibilidad, nos llama especialmente la atención la tierna y sonriente expresividad que revela el Niño, tono anímico que es más frecuente, como veremos, en la obra de Luisa y no tanto en la de su padre cuya producción suele mostrar expresiones más severas. Ciertos paralelos entre la forma de plegar los paños, observable entre esta obra y la del mismo tema que se atribuye unánimemente a Luisa Roldán en la iglesia de San Antonio de Cádiz, condujeron a Torrejón a barajar la posibilidad de adjudicársela también a la hija del maestro ${ }^{19}$.

Pero con independencia de la atribución casi unánime a Roldán de la pieza de la catedral y de estas dos últimas, más discutidas, quisiera proponer dos nuevas obras, hasta ahora bastante desconocidas, encuadrables en este mismo ambiente,

15 TORREJÓN DÍAZ, Antonio: "Luisa Roldán. San José”, en ROMERO TORRES, J. L. y TORREJÓN DÍAZ, A. (coords.): Roldana, op. cit., p. 186.

${ }^{16}$ El retablo en que está situada, datado en 1694-1698, estuvo dedicado originalmente a San Nicolás, de lo que se deduce que la imagen de San José procede de otro lugar.

${ }^{17}$ Agradezco a Roberto Alonso su opinión personal a este respecto.

18 GÓMEZ PIÑOL, Emilio: La iglesia Colegial del Salvador. Sevilla, 2000, pp. 421422.

19 TORREJÓN DÍAZ, A.: "Luisa Roldán. San José”, op. cit., p. 186. 
obras que tal vez conviniera contemplar entre las atribuibles a la joven Luisa Roldán en sus cerca de dos décadas de trabajos sevillanos. En primer lugar, podríamos mencionar la imagen de San José con el Niño, de tamaño natural, que se conserva en una capilla lateral de la iglesia parroquial de San Bartolomé de Sevilla (Figura 6).

Muestra la obra algunos rasgos que recuerdan a la hija de Pedro Roldán, en especial el hecho de que en este caso, no solo sonríe abiertamente el Niño, como sucede en la escultura de la iglesia colegial del Salvador, sino también su padre. Jesús, que en este caso no mira a San José sino al espectador, apoya su mano izquierda sobre el pecho en gesto de amor filial y alarga su brazo derecho para acariciar la barba del santo patriarca. En suma, parece estar revelando a quien observa la escena, sus sentimientos hacia su padre putativo. Dejo aquí simplemente apuntada esta hipótesis de atribución con la idea de madurarla más adelante y de recabar otras opiniones al respecto. Debo adelantar que tanto en esta primera propuesta como en la que a continuación detallaré algo más por considerar su atribución aún más segura, son los aspectos expresivos de los rostros y el tono afectivo de las actitudes de ambos personajes los rasgos que me han parecido más vinculables a la Roldana.

La obra que aquí más nos interesa está tallada en madera de cedro, mide 83 $\mathrm{cm}$ de altura y se conserva en la parroquia de Nuestra Señora de Gracia del municipio de Camas, junto a Sevilla. Se encuentra situada en la actualidad sobre una peana, colgada a cierta altura, en el frente de un pilar que separa la nave de la epístola de la central ${ }^{20}$. No sabemos cuándo fue instalada en este lugar pero sí consta por una antigua fotografía conservada en la Fototeca del Laboratorio de Arte de la Universidad de Sevilla, que estuvo albergada en una hornacina del banco de un sencillo retablo, hoy desaparecido, formado por molduras rococó y cuyo registro principal contenía un gran relieve de la Virgen de la Antigua, relieve que actualmente se encuentra en la capilla sacramental de la misma iglesia ${ }^{21}$. Nada más sabemos sobre este modesto retablo desaparecido ni sobre las dos obras a las que servía de marco. Esta imagen de San José con el niño, en razón de sus rasgos, debería ser datada en el último tercio del siglo XVII aunque su policromía parece corresponder a finales del siglo XVIII o inicios del XIX y a un gusto neoclásico al que igualmente obedece su peana, compuesta por un sobrio entablamento de triglifos y metopas dóricas sobre un arquitrabe cuya pintura imita mármoles veteados. Algunos indicios parecen indicar que la policromía original de la escultura

${ }^{20}$ Fue mencionada esta escultura como obra del siglo XVIII por HERNÁNDEZ DÍAZ, José; SANCHO CORBACHO, Antonio y COLLANTES DE TERÁN, Antonio: Catálogo Monumental de la Provincia de Sevilla. T. II. Sevilla, 1943, p. 18.

${ }^{21}$ Me advirtió amablemente de la existencia de esta fotografía Manuel Espinal Halcón a quien agradezco la noticia. 
pudiera subyacer a la que ahora se ofrece a la vista, policromía esta última que distorsiona la estética original de la escultura (Figura 7).

Pero, con independencia de su apariencia cromática original que, como suponemos, incluiría estofados y corladuras como otras obras de esta época, es el tratamiento de sus volúmenes y, sobre todo, los rasgos expresivos de los rostros los que nos sugieren su posible paternidad ya que son muy numerosos los que coinciden con otras interpretaciones que del tema hizo la escultora que aquí se propone como su posible autora.

Respecto de lo primero, la base de la figura es ancha y solo la punta de los pies asoma por debajo de la túnica que se apoya sobre el suelo. Los volúmenes del manto que la cubre son llamativamente ampulosos y logran conceder a la figura una cierta monumentalidad barroca que poseen otras obras de Luisa Roldán. El propio mantillo blanco ha sido inteligentemente dispuesto con objeto de que el cuerpo desnudo del Niño pueda ser visto con facilidad por quien lo observa. Revela esta obra un profundo conocimiento de la anatomía como sucede en otras figuras infantiles de Luisa Roldán, representando sus formas con las redondeces propias de un niño de apenas unos meses de edad. Las manos de San José, por el contrario, son huesudas, describiéndose en ellas con detalle falanges, tendones y venas.

Desde el punto de vista expresivo, llama la atención el cruce de miradas entre el padre y el Niño y el tono de afectividad que domina la expresión sonriente de ambos rostros. El Hijo posa, como el anterior, su mano izquierda sobre su pecho en clara señal de amor mientras mira a San José quien inclina hacia él su cabeza en un claro gesto de ternura. Y es la expresión del padre la que recibe un tratamiento más característico y original de Luisa Roldán pues sonríe de forma clara y desinhibida, dejando ver la dentadura de su boca entreabierta, en actitud de estar dedicando al Niño un requiebro cariñoso. Solo la Roldana en el contexto de la escultura barroca sevillana parece haberse atrevido a dar a una imagen sagrada una gestualidad tan efusiva y espontánea. Una escena de expresividad semejante la constituye su obra en terracota del San José con el Niño que se conserva en el convento granadino de San Antón, tal vez de etapa madrileña, aunque muchas otras imágenes de San José que ejecutó muestran esta misma expresión sonriente (Figura 8).

Y es en esta manera de interpretar la emotividad del rostro de San José en la que percibimos claros paralelos no solo con las versiones madrileñas sino también con las antes mencionadas en la parroquia sevillana de San Bartolomé y con la imagen de Antequera (Figuras 9, 10, 11 y 12).

Pero antes de plantear, finalmente, qué factores pudieron originar este cambio de expresión en los rostros, este aumento de afectividad entre los dos personajes, hagamos una puntualización en relación al tipo iconográfico que siguen todas las imágenes que aquí referimos. Algunos autores que se han ocupado del origen de este nuevo modelo iconográfico y de la supuesta primera interpretación que 
hiciera Pedro Roldán en su obra de la catedral de hacia 1664, han sugerido que pudiera haber tomado la idea de la escultura de este tema que hiciera Pedro de Mena para el retablo del convento del Ángel Custodio, de Granada (1653-1657), a partir -según Montalvo escribe en $1708^{22}$ - de un modelo de Cano. Esa obra canesca, hoy desaparecida, sería una versión escultórica de este modelo aunque ya había realizado Cano otras interpretaciones similares en pintura como atestigua un sugerente y documentado trabajo de Valiñas López ${ }^{23}$.

Con independencia de quién fuera el primer escultor que renovara el modelo iconográfico, asunto algo oscuro por el momento y necesitado de un estudio más detenido, podríamos ir un poco más allá y plantear la posibilidad de que todos estos cambios pudieran darse de forma simultánea en distintas partes del país, al calor de estímulos surgidos al margen de la actividad plástica de los artistas y más bien vinculados a la evolución de las creencias o a la manera de sentir las devociones durante esta fase barroca avanzada. Para ello vamos a realizar una simple comprobación en una obra literaria que considero tuvo una enorme trascendencia artística.

La mencionada comunicación de Valiñas proporciona las pautas generales de la evolución y valoraciones negativas y positivas de la figura de San José en las fuentes literarias desde la patrística clásica a los autores místicos modernos y resalta la carga positiva que la figura del padre putativo de Jesús revela en obras como La leyenda dorada, las Meditaciones del Pseudo Buenaventura y, sobre todo, las de Teresa de Jesús, alguno de cuyos textos menciona. En esta misma línea de sensibilidades literarias se inscribiría la obra del padre Gracián de la Madre de Dios y de otros teólogos del siglo XVII ${ }^{24}$. Cita también Valiñas la Mística Ciudad de Dios, obra de sor María Jesús de Ágreda aunque sin mencionar de ella párrafos concretos que aquí traeremos a colación por considerarlos entre los testimonios más reveladores -y sobre todo, más difundidos- de esa nueva sensibilidad que se percibe entre los creyentes españoles en relación con la figura de San José.

Es preciso recordar que la segunda redacción de la obra de la erudita monja de Ágreda -la primera la condenó a las llamas ella misma por consejo de su confesor-se hizo entre 1655 y 1660 aunque no fue publicada hasta 1670, un año antes de que Luisa Roldán se casara y emprendiera su labor profesional independiente.

22 DE MONTALVO Y PAlOMINO, Tomás: Crónica de la provincia de San Pedro del Alcántara... Primera parte. Granada, 1708, p. 424.

${ }^{23}$ VALIÑAS LÓPEZ, Francisco M.: "Sobre la recuperación de San José y su reflejo en el arte de Alonso Cano", en Actas del Simposium Internacional, Alonso Cano y su época. Granada, 2002, pp. 839-850.

${ }^{24}$ GRACIÁN DE LA MADRE DE DIOS, Gerónimo: Iosephina. Summario de las excelencias del glorioso S. Joseph, esposo de la Virgen María. Roma, 1597. Hubo ediciones posteriores en Madrid, 1601; Barcelona, 1605; Toledo, 1606; Bruselas, 1609; etc. 
Es preciso adelantar que no sostengo que las obras escultóricas de las que aquí me ocupo estuviesen inspiradas tan solo en la lectura de esta obra literaria sino más bien que esta última pudiera haber verbalizado teorías y sensibilidades que flotaban en el ambiente y, sobre todo, que las fomentara ampliamente por todo el mundo hispánico si consideramos sus múltiples ediciones. Su lectura, desde luego, ilumina con fuerza las obras que aquí nos interesa contextualizar. Concretamente hay varios textos de sor María Jesús que aluden a cómo María se afanaba en cuidar a su hijo y también a cómo San José se ocupaba personalmente de ayudarla en la tarea.

Comentando las incomodidades de la primera residencia de la Sagrada Familia donde Jesús vino al mundo escribe: “...como aquel puesto (el portal de Belén) era desacomodado y tan expuesto a las inclemencias del tiempo, estaba la gran Señora más cuidadosa del abrigo de su tierno y dulce infante y, como prudentísima, trajo prevenido un mantillo con que abrigarle 25 a más de los fajos ordinarios, y cubriéndole con él, le tenía continuamente en el sagrado tabernáculo de sus brazos, si no es cuando le (sic) daba a su esposo san José que, para hacerle más dichoso, quiso también le ayudase en esto y sirviese a Dios humanado en el ministerio de padre"26.

La monja de Ágreda insiste en los detalles al narrar este episodio y así escribe: "La primera vez que el santo esposo recibió al niño Dios en los brazos le dijo María Santísima: Esposo y amparo mío, recibid en vuestros brazos al Criador del Cielo y Tierra y gozad su amable compañía y dulzura para que mi Señor y Dios tenga en vuestro obsequio sus regalos y delicias" ${ }^{27}$. Se alude aquí, por tanto, al momento de la entrega del Niño y al carácter tierno del encuentro paterno-filial que tan claramente se describe en nuestras esculturas. Por cierto, el mismo acto del intercambio del Niño entre José y María es el episodio representado en un grupo atribuido con gran seguridad a Luisa Roldán que se conserva en el monasterio de Nuestra Señora de la Piedad, de franciscanas descalzas, de Cádiz, donde, con seguridad, la obra de la monja de Ágreda sería de lectura asidua como en todas las clausuras femeninas lo ha sido hasta época muy reciente.

Más adelante, la monja visionaria vuelve a insistir sobre esta imagen en un pasaje en que el Niño Dios, a pesar de su tierna edad, dicta a su madre con imperativa resolución el orden de sus tareas diarias, expresándose concretamente con las siguientes palabras: "Madre mía carísima, desde entrada la noche dormiréis y descansaréis algo y desde media noche hasta el amanecer os ocuparéis en los ejercicios de la contemplación conmigo y alabaremos a mi eterno Padre; luego

${ }^{25}$ Como puede verse por nuestras cursivas, el texto alude explícitamente al mantillo que aparece en nuestro tipo iconográfico.

${ }^{26}$ DE ÁGREDA, María Jesús: Mística ciudad de Dios. Segunda parte, lib. IV, cap. 12, vers. 504 .

${ }^{27}$ Ibidem, vers. 505. 
acudiréis a lo necesario para prevenir vuestra comida y de José; después, a darme a mí el alimento y me tendréis en vuestros brazos hasta la hora de tercia, que me pondréis en los de vuestro esposo para alivio de su trabajo..."28. La monja de Ágreda en este párrafo parece estar parafraseando las propias normas de vida diaria de su convento. Resulta inevitable, al leer este pasaje, que no acuda a la memoria la imagen del cuadro de Murillo que representa La Sagrada Familia del pajarito, del Museo del Prado.

Una cuarta oportunidad encuentra la religiosa para describir la entrega del Niño a José, en la que insiste en el efecto relajante que tendría para él tan entrañable tarea: "Esposo mío, recibid en vuestros brazos al Señor que contiene en su puño todos los orbes del cielo y tierra, a quienes dio el ser por sola su bondad inmensa. Y aliviad vuestro cansancio con el que es la gloria de todo lo criado. Este favor -continúa la monja de Ágreda- agradecía el santo con profunda humildad y solía preguntar a su esposa divina si se atrevería él a mostrar al niño alguna caricia. Y asegurado de la prudente Madre, lo hacía y con este alivio olvidaba la molestia de su trabajo y todos se le hacían fáciles y muy dulces"29. Este último texto parece ser una descripción literal de la obra de la iglesia de Camas en que la expresión de José refleja a partes iguales, respeto, cariño y ternura.

Sabemos que el trato cercano que la monja de Ágreda dispensa en su obra literaria a la Virgen María y a su familia y el tono doméstico que otorga a las escenas de costumbre que narra fueron algunos de los aspectos de su obra escrita que más sospechas de heterodoxia e incluso, irreverencia, despertaron en las autoridades eclesiásticas. A pesar de ello, la obra obtuvo desde el principio, un éxito sin precedentes de lectores a niveles populares y no tan populares pues muchos de los teólogos e intelectuales de la Iglesia no pudieron ignorar el efecto catequético que la obra ejercía en las comunidades religiosas y también entre los devotos seglares. La figura de San José y su incómodo papel de simple padre putativo fue, incluso, tema de comedias cargadas de sentido del humor lo que rozaba ya un terreno arriesgado ante los ojos de la Inquisición y de los censores eclesiásticos. Por ejemplo, Christoval de Monroy y Silva (1612-1649) escribió una comedia famosa titulada Los Zelos de San Joseph, de la que se hicieron múltiples ediciones, algunas de ellas en Sevilla, tras la muerte de su autor, e incluso adaptaciones simplificadas en versión de pliegos de cordel que llegaron hasta el siglo XVIII.

Pero es obvio que gran parte del éxito editorial de la obra de la monja de Ágreda debió residir precisamente en el tono cercano de su narración, en la fácil identificación de los lectores con los personajes sagrados y en el estímulo continuo del mundo de los afectos de los destinatarios de la obra. Nada debe extrañar, por tanto, que la clientela de los artistas, familiarizada con esta visión imaginativa y humanizada hasta extremos sorprendentes de la vida de la Virgen María,

${ }^{28}$ Ibid., cap. 25, vers. 658.

${ }^{29}$ Ibid., vers. 661.

LABORATORIO DE ARTE 29 (2017), pp. 377-396, ISSN 1130-5762 e-ISSN 2253-8305 - DOI http://dx.doi.org/10.12795/LA.2017.i29.20 
reclamase la ejecución de obras plásticas y teatrales en sintonía con estas narraciones que tan eficazmente estimulaban sus devociones y ayudaban a memorizar las historias sagradas. La Roldana, mujer letrada, debió conocer de manera directa la obra de sor María Jesús ya en su juventud sevillana ya en su etapa cortesana, trabajando para Carlos II, tan admirador de la autora como lo fue su padre y tan defensor de su beatificación en contra de los juicios condenatorios que llegaban desde Roma.

Carlos II no solo se interesó personalmente en los destinos de esta obra literaria y de su polémica autora a cuya benefactora intercesión, según pensaba él, debía su propia concepción, sino que dio pasos muy enérgicos en otro terreno igualmente conflictivo y vinculado con la devoción a San José. Su culto, a fines del siglo XVII ya tenía una larga tradición en España donde la orden del Carmelo lo había fomentado desde el siglo anterior, pero en tiempos del reinado de Carlos II (1665-1700) adquiere un especial relieve. Es muy significativo que el monarca solicitara al papa y consiguiera que éste publicara un breve por el cual el llamado Glorioso Patriarca debía ser tenido por santo patrón y tutelar de todos sus reinos. El 26 de diciembre de 1678 el rey envía un decreto comunicando el breve papal a virreyes, presidentes, audiencias, gobernadores, arzobispos, obispos, cabildos de ciudades y de catedrales. La medida provocó la inmediata reacción adversa de los canónigos de Santiago de Compostela que presionaron cerca del rey para que tal patronazgo no fuera puesto en práctica por cuanto estimaban lesionados sus derechos históricos derivados de ser el apóstol Santiago, patrón de España ${ }^{30}$. El rey se vio obligado a enviar nuevos comunicados invalidando su orden anterior pero, con independencia del resultado final de este episodio, no deja de ser revelador del auge que la devoción a San José llegó a adquirir en los reinos peninsulares y en los virreinatos americanos. En una época ya tan lejana a la Reconquista y en la que, por tanto, la amenaza islámica se consideraba desaparecida, tal vez resultara más adecuado un patrón de los reinos hispánicos menos militar y más paternal.

No es extraño por todo ello que durante el último tercio del siglo XVII proliferaran sus imágenes en pintura y escultura y que Luisa Roldán viviera este ambiente favorable tanto en Sevilla como en la corte. Tampoco era imprevisible que por las mismas razones se produjesen cambios iconográficos que hicieran sintonizar el asunto con nuevas sensibilidades de la devoción popular y de las numerosas monjas lectoras, siempre más proclives al mundo de los sentimientos que a sesudas reflexiones teológicas. Numerosos testimonios de este nuevo enfoque nos ofrece también el rico patrimonio de nuestros villancicos populares algunos de los cuales abordan, como estas esculturas y como los textos de la monja literata, los tiernos lazos sentimentales que unen la figura del Niño Jesus y su padre putativo.

${ }^{30}$ Archivo de la Catedral de Salamanca (A.C.S.), cajón 17, leg. 1, docs. 16 y 30. 
La pregunta que nos formulan estas nuevas esculturas atribuidas aquí a La Roldana es si es precisamente este tono descriptivo del asunto, cargado de sentimientos e incluso de sentido del humor es lo que mejor caracteriza las de San José con el Niño talladas por la artista sevillana y lo que las diferencia de las interpretaciones que del mismo tema hicieron su padre y los demás colegas contemporáneos. Queden aquí estas reflexiones como nuevos elementos de juicio para este debate al que, según espero, otros harán aportaciones más clarificadoras.

Fecha de recepción: 30 de enero de 2017

Fecha de aceptación: 9 de febrero de 2017 

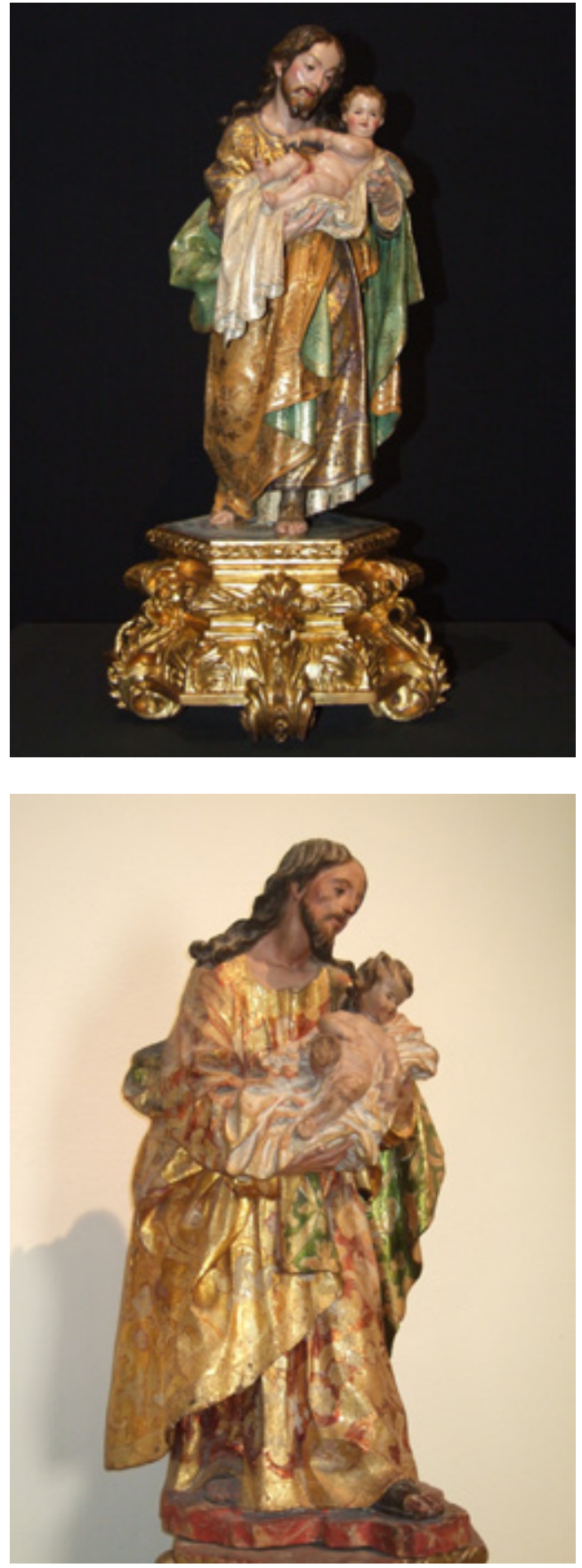

Figura 1. San José con el Niño, convento de Nuestra Señora de Belén, Antequera (Málaga).
Figura 2. San José con el Niño, Museo de la Catedral de Salamanca. Foto: Alfonso Pleguezuelo. 
Figura 3. San José con el Niño, convento de Madre de Dios, Sevilla. Foto: Alfonso Pleguezuelo.

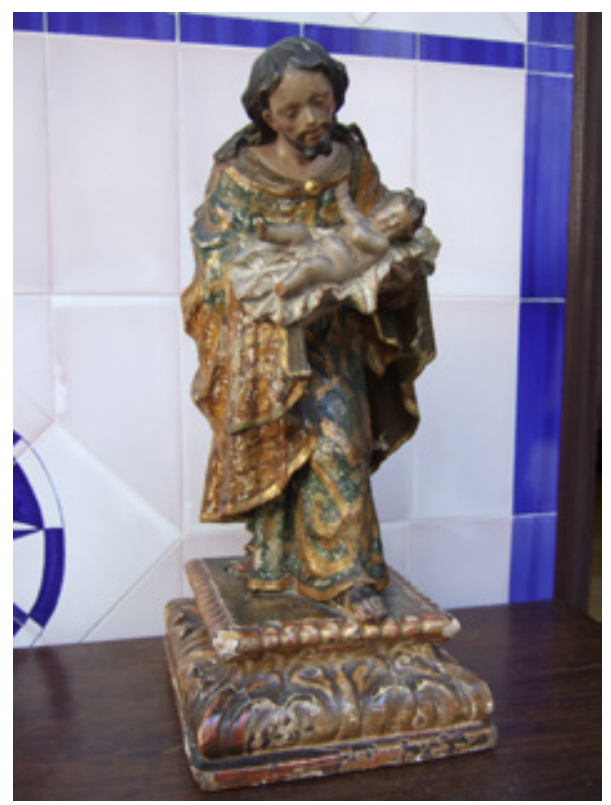

Figura 4. San José con el Niño, retablo mayor del convento de Santa Ana, Sevilla. Foto: Pedro Feria.

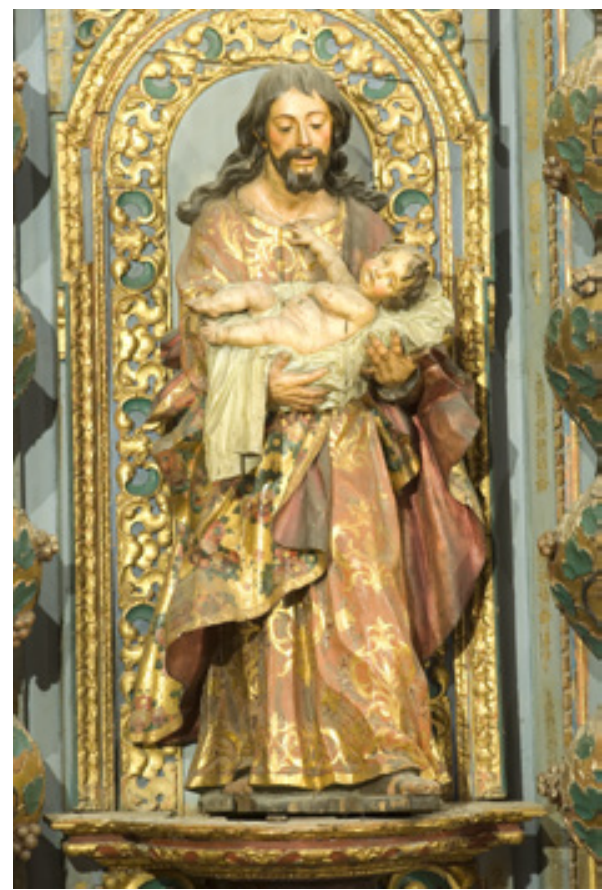

LABORATORIO DE ARTE 29 (2017), pp. 377-396, ISSN 1130-5762 e-ISSN 2253-8305 - DOI http://dx.doi.org/10.12795/LA.2017.i29.20 


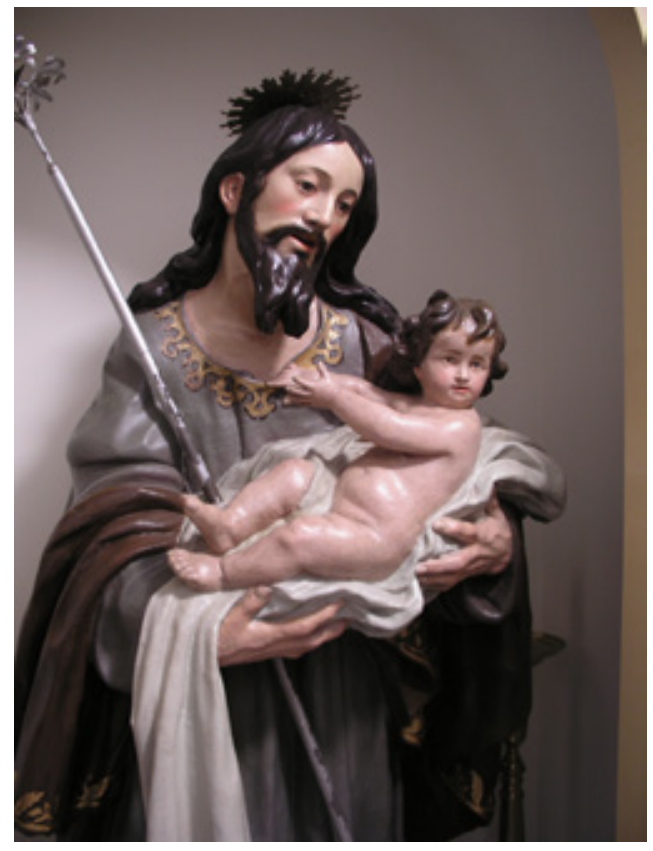

Figura 5. San José con el Niño, convento de Santa María de Jesús, Bormujos (Sevilla). Foto: Francisco Herrera.

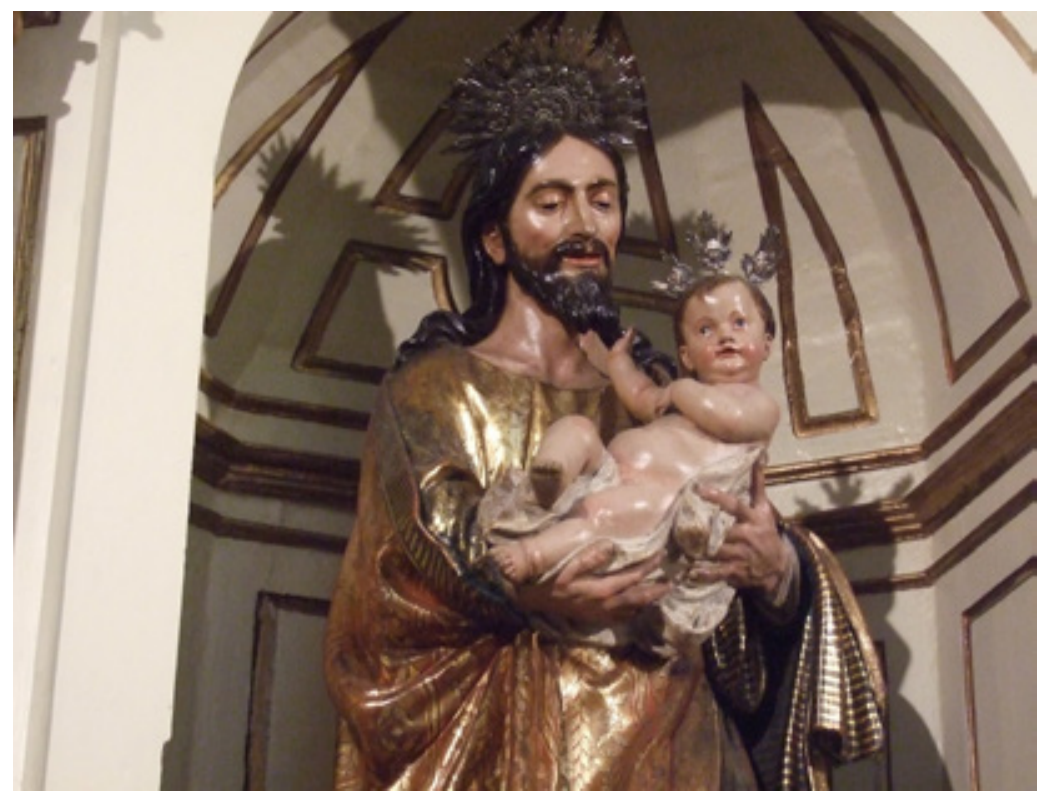

Figura 6. San José con el Niño, iglesia parroquial de San Bartolomé, Sevilla. Foto: Alfonso Pleguezuelo. 


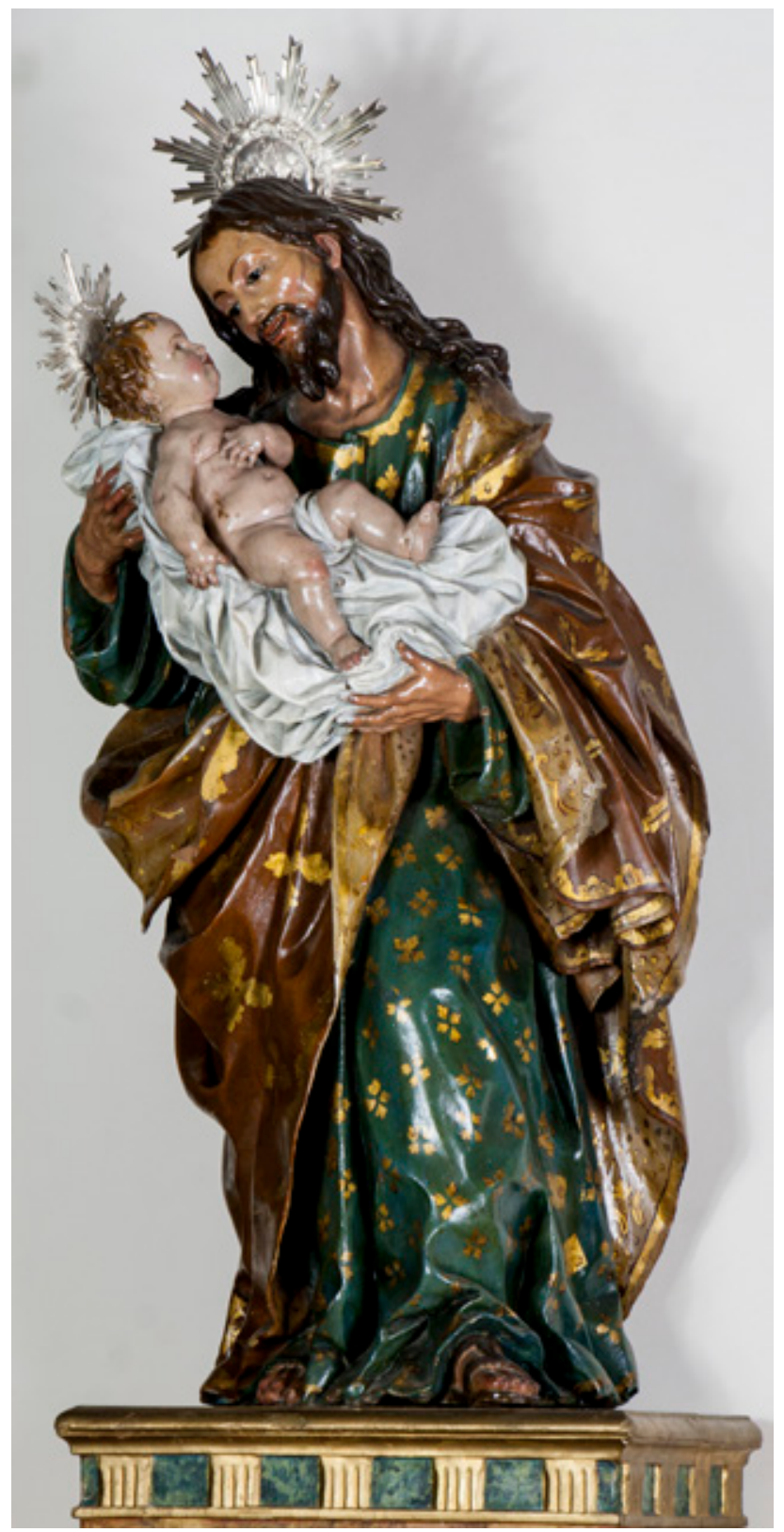

Figura 7. San José con el Niño, iglesia parroquial de Nuestra Señora de Gracia, Camas (Sevilla). Foto: Pedro M. Martínez Lara.

LABORATORIO DE ARTE 29 (2017), pp. 377-396, ISSN 1130-5762 e-ISSN 2253-8305 - DOI http://dx.doi.org/10.12795/LA.2017.i29.20 


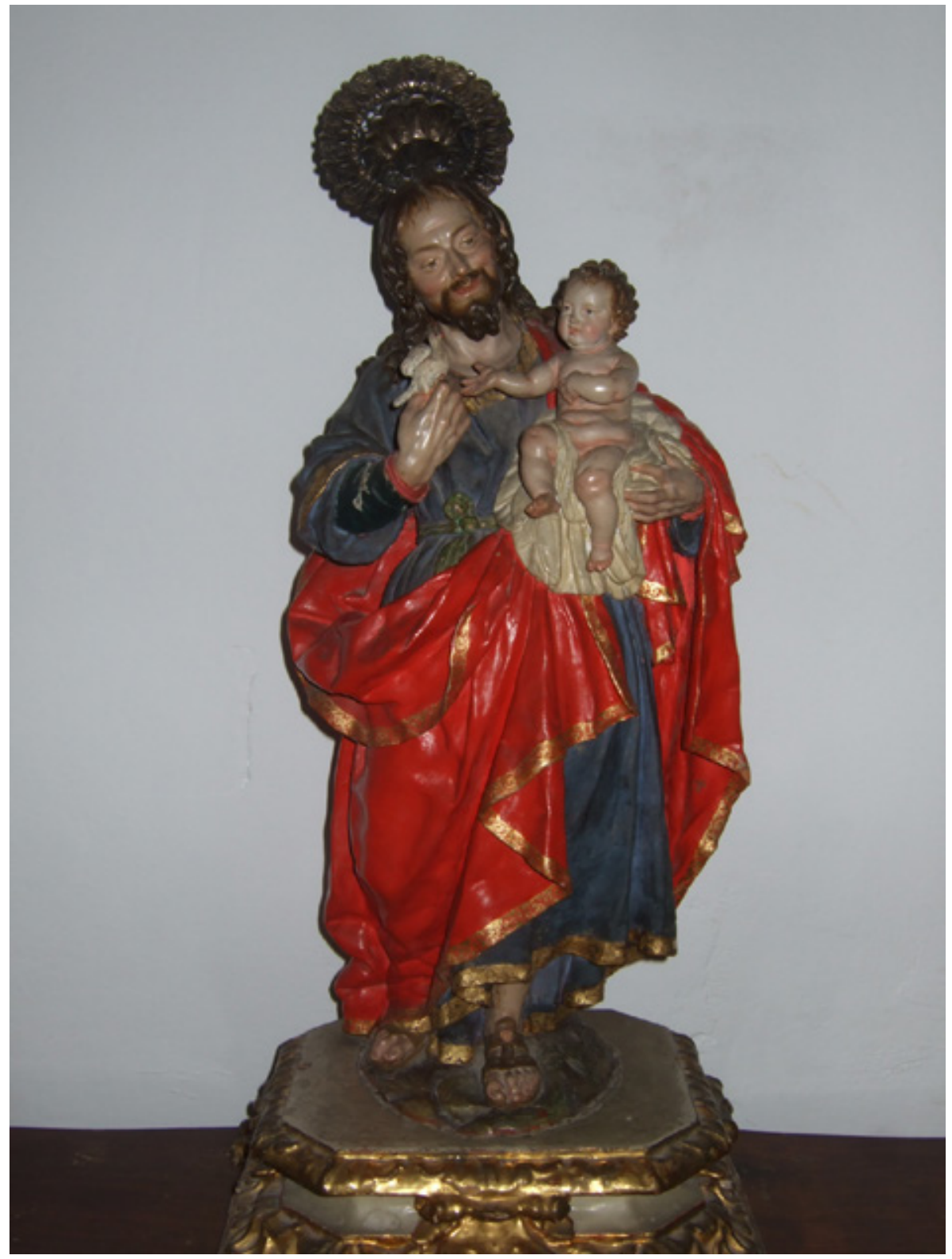

Fig. 8. San José con el Niño, convento de San Antón, Granada. Foto: Alfonso Pleguezuelo. 


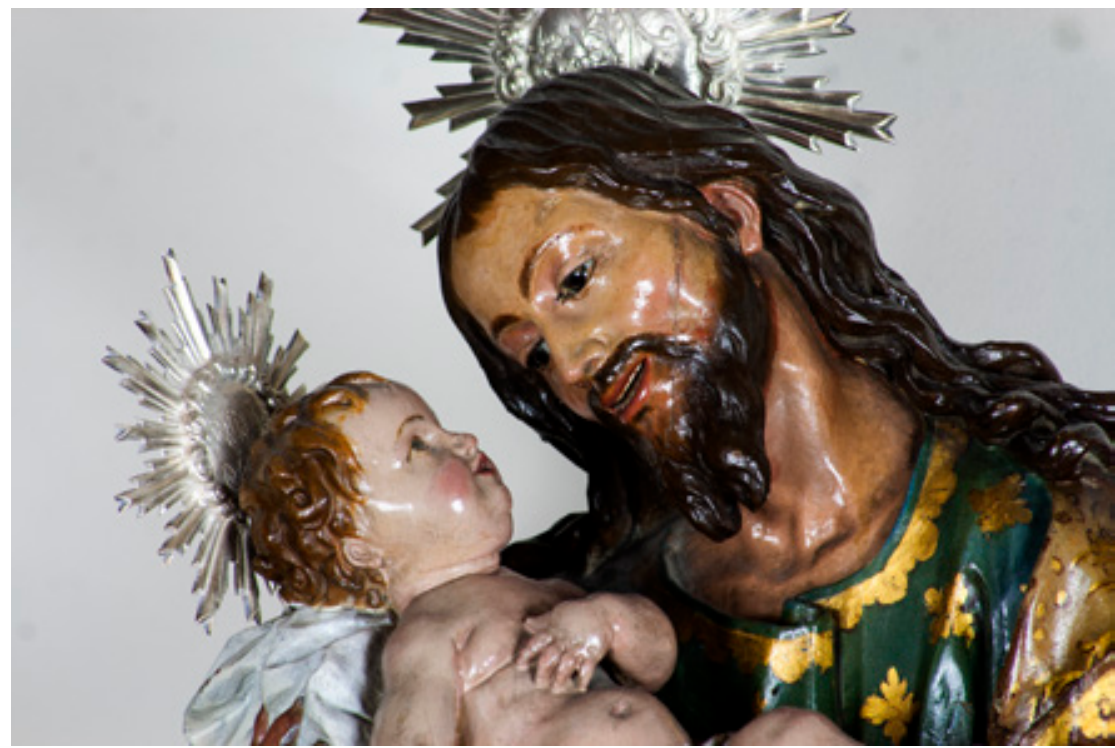

Figura 9. San José con el niño, iglesia de Nuestra Señora de Gracia, Camas (Sevilla). Foto: Pedro M. Martínez Lara.

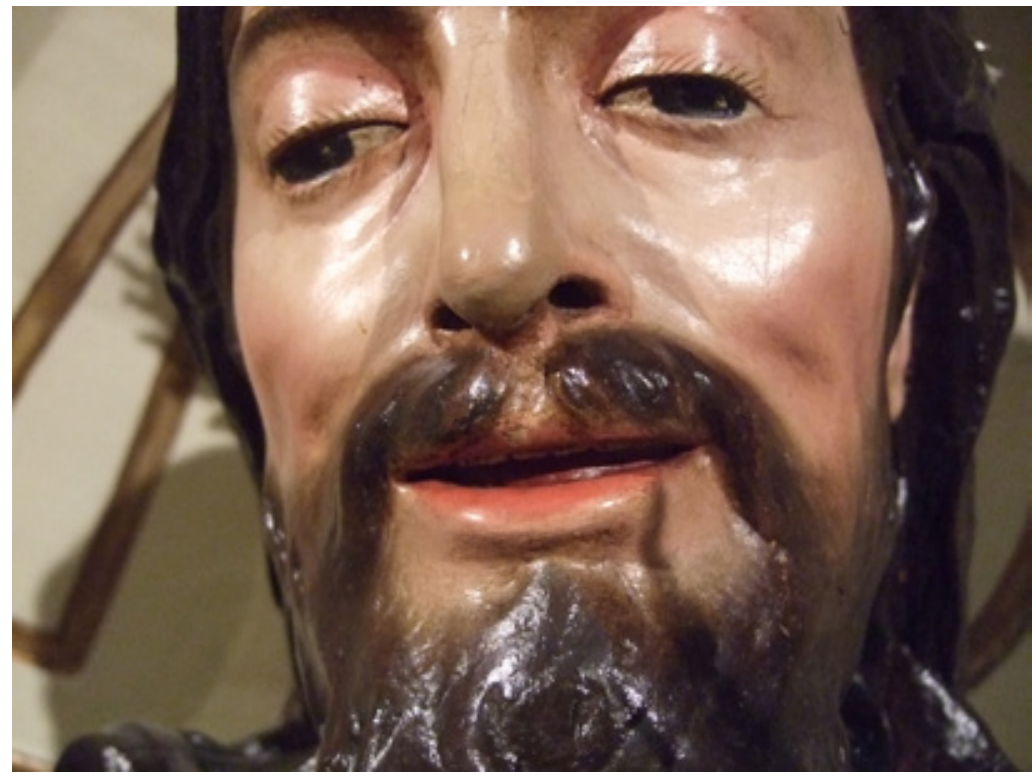

Figura 10. San José con el Niño, iglesia de San Bartolomé, Sevilla. Foto: Alfonso Pleguezuelo. 


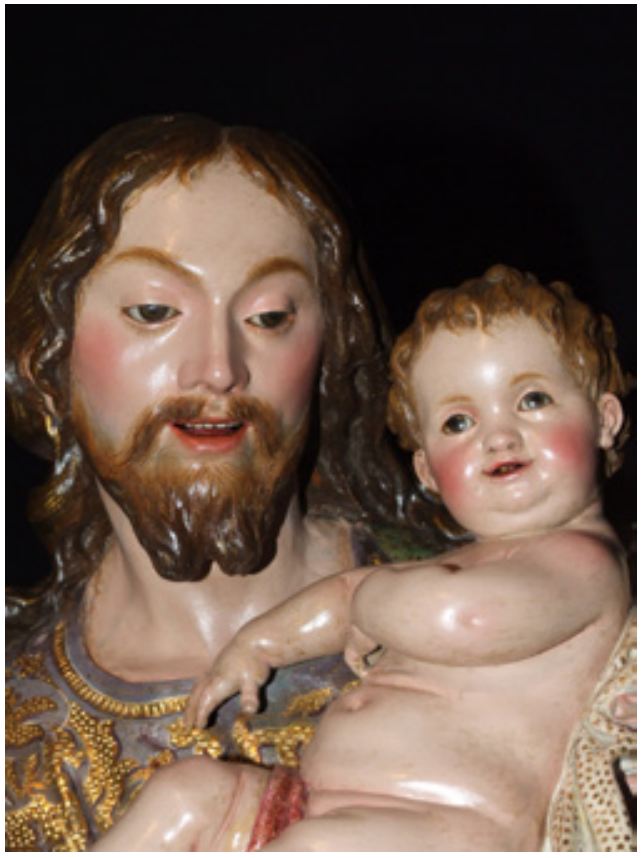

Figura 11. San José con el Niño, convento de El Carmen, Antequera (Málaga). Foto: Alfonso Pleguezuelo.

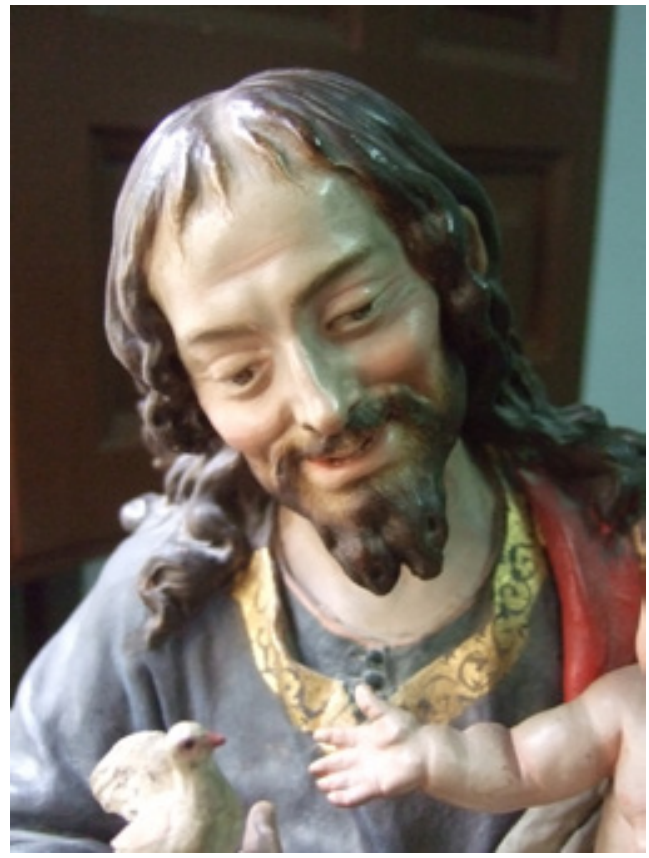

Figura 12. San José con el Niño, convento de San Antón, Granada. Foto: Alfonso Pleguezuelo. 